\title{
Dermatologic conditions in teenage adolescents in Nigeria
}

This article was published in the following Dove Press journal:

Adolescent Health, Medicine and Therapeutics

27 May 2014

Number of times this article has been viewed

\section{Eshan B Henshaw' \\ Olayinka A Olasode ${ }^{2}$ \\ Evelyn E Ogedegbe ${ }^{3}$ \\ Imaobong Etuk ${ }^{4}$}

'Dermatology Unit, Department of Internal Medicine, University of Calabar, Calabar, Cross River State, ${ }^{2}$ Department of Dermatology, Obafemi Awolowo University, Ile-Ife, Osun State, ${ }^{3}$ Cedarcrest Hospital, Abuja, Federal Capital Territory, ${ }^{4}$ Department of Pediatrics, University of Calabar, Calabar, Cross River State, Nigeria
Correspondence: Eshan B Henshaw Department of Medicine, Faculty of Clinical Sciences, College of Medical Sciences, University of Calabar, P.M.B II I 5 Calabar, Cross River State, Nigeria Email eshanbisong@yahoo.co.uk
Background: Skin disorders are common in adolescents, and the impact on quality of life can be enormous, particularly when viewed against the backdrop of the visibility of skin diseases and the psychologically vulnerable period of adolescence. However, few studies have documented the magnitude of skin disorders in this subset of individuals. We therefore estimated the point prevalence and pattern of dermatologic conditions in adolescents attending various secondary schools in Calabar, Southern Nigeria.

Methods: Using a structured questionnaire, relevant sociodemographic information was obtained from 1,447 teenage adolescents from eight secondary schools. Thereafter, a whole body examination was conducted to determine the presence and types of skin disorders seen. Results: Skin diseases were seen in 929 students. The point prevalence was higher in males $(72.1 \%)$ than in females $(58.3 \%)$. Private schools had a higher prevalence than public schools. The six most common dermatoses were acne vulgaris, pityriasis versicolor, nevi, tinea, miliaria, and keloid/hypertrophic scars, and accounted for over $80 \%$ of the dermatoses seen.

Conclusion: The point prevalence of dermatoses in senior secondary school adolescents was $64.2 \%$. Although a large number of skin disorders were observed, only a handful accounted for a significant proportion of the diseases seen. This increases the ease of training community health workers in the recognition and treatment of common skin diseases. Age, race, and climatic factors are important determinants of skin diseases in adolescents in Nigeria.

Keywords: skin diseases, adolescents, Nigeria

\section{Introduction}

The World Health Organization defines adolescents as persons aged 10-19 years. ${ }^{1}$ Nigeria is estimated to have a population of 174 million people, and about $22 \%$ of these are adolescents, accounting for an adolescent population of 38 million. ${ }^{2,3}$ This number is greater than the entire population of Canada, and more than the sum of the estimated population of three of Nigeria's northernmost boundary countries, ie, Benin, Niger, and Chad. ${ }^{2}$ This is a large population whose health needs must be determined, given that the effects of poor health during the teenage years can last for a lifetime. Adolescence is an important transition phase in life, representing a link between the complete dependency of childhood and the total independence of adulthood. The period of adolescence is marked by myriad changes occasioned by the interplay of hormones during puberty. Appearance is altered on account of secondary sexual characteristics, and some of these alterations may be due to skin diseases such as acne vulgaris, which is almost universal in adolescence and has been associated with depression and suicide. ${ }^{4}$ Golics et $\mathrm{al}^{5}$ found that skin diseases had a significant negative impact on 
health-related quality of life in adolescents. Skin disorders are among the most common presenting health problems and pose a significant public health burden both in developing and developed countries. ${ }^{6}$ Children and adolescents are more prone to developing skin diseases than adults because they are more often exposed to climatic and social conditions that make them more likely to develop skin infections and to suffer minor skin injuries. Skin diseases are also among the most frequent diseases of school children over a third of whom are affected at any given time. ${ }^{7,8}$ The school environment makes students vulnerable to cross-transmission of communicable skin diseases, because they engage in activities that involve interpersonal contact, especially at game or play. ${ }^{9}$

In many studies assessing the pattern of skin diseases, children and adolescents are regarded as a homogeneous group, but there are some significant differences in the pattern of skin diseases in these two groups. Adolescents are susceptible to a variety of dermatoses, many of which are as a result of the physiologic changes encountered during puberty. Only one study of the epidemiology of skin diseases exclusively in Nigerian adolescents was found, and this was done in the south-western part of the country. ${ }^{10}$ The burden of skin disease in absolute terms is said to be the product of its morbidity multiplied by its prevalence. ${ }^{11}$ This burden is virtually unknown in adolescents, due to the paucity of dermatoepidemiologic surveys exclusively in this age group. Researchers often limit their surveys to children and younger adolescents to increase participation and enable unrestricted examination. ${ }^{12,13}$ Epidemiologic data are essential to determine the size and importance of a health problem and define priorities with a view to offering solutions. This study thus seeks to determine the prevalence and pattern of skin diseases among in-school adolescents in Calabar, the capital city of Cross River State in the South-Eastern region of Nigeria.

\section{Materials and methods}

This was a cross-sectional study of the pattern of skin diseases in senior secondary school students aged 13-19 years and attending non-boarding, mixed, day, public, or private schools in Calabar. Permission was obtained from the ethics committee of the University of Calabar Teaching Hospital and from the Commissioner for Education at the Cross River State Ministry of Health.

There are 77 registered public and private secondary schools in the region, 35 of which met the criteria for participation. We included non-boarding, coeducational, and day secondary schools. Thus, boarding, exclusively boys or girls schools, and night schools were excluded.
A multistage stratified random sampling technique with proportional allocation was used to select participants for the study as follows: schools were first subclassified by type into two groups depending on the amount of tuition fees paid. Public schools were designated as low profile ( $\$ 2,400 \approx \$ 16$ USD per annum), and private schools as high profile ( $\geq \$ 35,000 \approx \$ 700$ per annum). Using a simple random sampling method (balloting), eight schools were selected, comprising four each from the 19 public and 16 private schools. The exact number of students in senior secondary classes (SS 1-3) from each school was obtained and used to determine the number of students to be recruited from each school. The number of students to be recruited was proportionally allocated among the schools. All of the senior secondary classes and their class divisions, also known as arms, were involved. A serial list of senior secondary students as it appears on the class register was obtained and a simple random sampling technique using a table of random numbers was then used to select the desired number of students. This ensured that any child in the senior secondary class could have been recruited. A semistructured self-administered questionnaire was developed, and after pretesting among a group of senior secondary school students in a school not included in the study, was then distributed to the selected students in the sample population. The students were asked to supply information on sociodemographic characteristics, parental occupation, education, and income, personal hygiene, and household characteristics. Knowledge of the presence and type of skin disease and their reaction to this was also obtained.

The students were required to study the questionnaires, and any queries regarding the contents therein were answered by the investigators. They were then allowed to take the questionnaires home because they would need the help of their parents/guardians in supplying answers to some of the questions. Thereafter, the selected students underwent a whole body examination, irrespective of the presence or absence of self-reported skin lesions. All observed skin findings were recorded, irrespective of their severity; diagnoses were mostly clinical, but often supported by laboratory investigations when indicated. Classification was based on the modified Tenth Revision of the International Classification of Disease (ICD-10) ${ }^{14}$ and Rook's Textbook of Dermatology. ${ }^{15}$ Data collected through questionnaires were collated and captured into a spreadsheet, where they were modeled to meet the different criteria needed for statistical analysis.

The data were then entered into Statistical Package for the Social Sciences version 15 software (SPSS Inc., 
Chicago, IL, USA) for analysis and testing. Various statistical techniques such as mean, cross-tabulation and the chi-squared test were used to obtain descriptive statistics, depending on the objectives to be met.

The cross-tabulation procedures provided two way and multi-way tables, and also provided a variety of tests and measures of association for the tables. Tests to compare means included one-way analysis of variance. The level of statistical significance was fixed at $P \leq 0.05$.

\section{Results}

A total of 1,541 students spread across the eight selected schools were recruited for the survey, of which 1,447 students eventually participated, giving a response rate of $93.9 \%$. Reasons for the $6.1 \%$ attrition rate included lack of parental consent, failure to return completed questionnaires, absenteeism on the day of examination, and refusal to allow whole body examination. There were 996 students from public schools (mean age 15.6 \pm 1.5 years) and 451 students from private schools (mean age 14.8 \pm 1.3 years). Males accounted for $42.8 \%$, while females made up the rest $(57.2 \%)$, resulting in a male to female ratio of $1: 1.3$. For the purpose of this study, students were grouped into two distinct age groups, ie, 13-16 years (younger adolescents) and 17-19 years (older adolescents). The ratio of older adolescents to younger adolescents in the study was 1:3.7 (the ratio in public schools was 1:2.8 while that in private schools was 1:9.4). Details of sociodemographic characteristics are shown in Table 1. The overall point prevalence of skin diseases was $64.2 \%$, with a greater prevalence in males $(72.1 \%)$ than in females $(58.3 \%, P<0.05)$.

A total of 42 specific dermatologic disorders were seen and these were divided into seven categories, which in descending order of frequency included: disorders of skin appendages, infections/infestations, disorders of pigmentation, eczema/dermatitis, hypertrophic/atrophic skin disorders, disorders of keratinization, and miscellaneous disorders. Acne vulgaris was solely responsible for the predominance of disorders of skin appendages (40.8\%); it was also the most common condition in the study (35.1\%). Miliaria which was in the same category and among the common conditions in the study, accounted for $4.2 \%$ of the total number of skin diseases seen. Infection/infestation was the second most predominant category in the study, and this was on account of pityriasis versicolor (29.7\%) which was the second most common condition in the study, and about seven times more common than its closest rival in the group, ie, dermatophytosis (4.3\%). Papular urticaria
Table I Sociodemographic characteristics of study population

\begin{tabular}{|c|c|c|c|}
\hline \multirow[t]{2}{*}{ Factors } & \multicolumn{2}{|c|}{ School type n (\%) } & \multirow{2}{*}{$\begin{array}{l}\text { Total number } \\
\text { in group (\%) }\end{array}$} \\
\hline & $\begin{array}{l}\text { Public } \\
(n=996)\end{array}$ & $\begin{array}{l}\text { Private } \\
(n=45 I)\end{array}$ & \\
\hline \multicolumn{4}{|l|}{ Age (years) } \\
\hline $13-16$ & $734(73.6)$ & 407 (90.7) & $\mathrm{I}, \mathrm{I} 4 \mathrm{I}(78.9)$ \\
\hline $17-19$ & $262(26.3)$ & $44(9.75)$ & $306(21.1)$ \\
\hline \multicolumn{4}{|l|}{ Gender } \\
\hline Males & $397(39.8)$ & $222(49.2)$ & $619(42.8)$ \\
\hline Females & $599(60.2)$ & $229(50.7)$ & $828(57.2)$ \\
\hline \multicolumn{4}{|l|}{ Class } \\
\hline SS I & $425(42.6)$ & $65(14.4)$ & $590(40.9)$ \\
\hline SS 2 & $436(43.7)$ & 152 (33.7) & $588(40.8)$ \\
\hline SS 3 & $132(13.2)$ & $132(29.2)$ & $264(18.3)$ \\
\hline \multicolumn{4}{|l|}{ Tribe } \\
\hline Efik & $260(26.1)$ & $124(27.4)$ & $384(26.8)$ \\
\hline Ejagham & $189(18.9)$ & $26(5.76)$ & $215(15.0)$ \\
\hline $\begin{array}{l}\text { Minor tribes in } \\
\text { CRS }\end{array}$ & $119(11.9)$ & $40(8.86)$ & $159(11.1)$ \\
\hline Ibibio/Annang & $294(29.5)$ & I 34 (29.7) & 428 (29.9) \\
\hline Igbo & $66(6.6)$ & $59(13.0)$ & $125(8.7)$ \\
\hline Yoruba & $18(1.8)$ & $35(7.76)$ & $53(3.7)$ \\
\hline Others & $47(4.7)$ & $21(4.65)$ & $68(4.8)$ \\
\hline \multicolumn{4}{|l|}{ Religion } \\
\hline Christianity & 985 (98.9) & $436(96.6)$ & I,42I (98.3) \\
\hline Islam & $5(0.5)$ & $8(1.77)$ & $13(0.9)$ \\
\hline Others & $6(0.6)$ & $5(1.10)$ & II (0.8) \\
\hline
\end{tabular}

Abbreviation: CRS, Cross River State; SS, senior secondary.

had a point prevalence of $3.3 \%$, while viral warts accounted for less than $1 \%$. There were three types of nevoid conditions identified, with melanocytic nevus predominating, followed by achromic nevus (nevus depigmentosus). Post inflammatory hyperpigmentation came second on the list of pigmentary disorders, accounting for $19.8 \%$ of this group and $1.8 \%$ of all skin diseases. There was only one case of vitiligo. More than half the cases of dermatitis were due to contact dermatitis, which had a prevalence of approximately $3 \%$. Only 12 students had seborrheic dermatitis and fewer still had signs meeting the criteria for a diagnosis of atopic dermatitis. Two conditions, keloids and striae, constituted the hypertrophic/atrophic skin disorders. Hypertrophic skin disorders (keloid/hypertrophic scars) were twice as common as disorders of skin atrophy (striae). Table 2 shows the detailed categorization of all dermatoses, including their point prevalence.

There were evident gender differences in the point prevalence of the sum of all skin conditions and in certain specific skin diseases. Dermatophytosis, pityriasis versicolor, and melanocytic nevi were significantly more common in males $(P=0.001)$. Miliaria was seen more in females but this was not statistically significant $(P=0.58)$. Table 3 shows the details of some of the observed sex differences. 
Table 2 Categories of skin diseases and their point prevalence

\begin{tabular}{|c|c|c|c|}
\hline Category frequency (\%) & Skin disease & $\begin{array}{l}\text { Frequency } \\
\text { (\% in group) }\end{array}$ & $\%$ of total \\
\hline \multirow[t]{6}{*}{ Disorders of skin appendage $(591,40.8)$} & Acne vulgaris & $509(86.1)$ & 35.1 \\
\hline & Miliaria & $61(10.3)$ & 4.2 \\
\hline & Alopecia & $8(1.4)$ & 0.6 \\
\hline & Folliculitis & $7(1.2)$ & 0.5 \\
\hline & Nail dystrophy & $5(0.8)$ & 0.3 \\
\hline & Sycosis cruris & $\mathrm{I}(0.2)$ & 0.1 \\
\hline \multirow[t]{10}{*}{ Infections/infestations $(550,37.9)$} & Pityriasis versicolor & $430(78.1)$ & 29.7 \\
\hline & Dermatophytosis & $62(11.3)$ & 4.3 \\
\hline & Papular urticaria & $18(3.3)$ & 1.2 \\
\hline & Candidiasis & $14(2.6)$ & 1.0 \\
\hline & Furuncules & $9(1.6)$ & 0.6 \\
\hline & Viral warts & $9(1.6)$ & 0.6 \\
\hline & Scabies & $4(0.7)$ & 0.2 \\
\hline & Trichomycosis axillaris & $2(0.4)$ & 0.1 \\
\hline & Hansen's disease & $\mathrm{I}(0.2)$ & 0.1 \\
\hline & Herpes simplex & $\mathrm{I}(0.2)$ & 0.1 \\
\hline \multirow[t]{8}{*}{ Disorders of pigmentation (I3I, 9.I) } & Melanocytic nevi & $74(56.5)$ & 5.1 \\
\hline & Post inflammatory pigmentation & $26(19.8)$ & 1.8 \\
\hline & Achromic nevus & $15(11.4)$ & 1.0 \\
\hline & Epidermal nevus & $7(5.3)$ & 0.5 \\
\hline & Acanthosis nigricans & $4(3.1)$ & 0.3 \\
\hline & Freckles & $3(2.3)$ & 0.2 \\
\hline & Fixed drug eruption & I (0.8) & 0.1 \\
\hline & Vitiligo & $\mathrm{I}(0.8)$ & 0.1 \\
\hline \multirow[t]{7}{*}{ Dermatitis $(74,5.1)$} & Contact dermatitis & $42(56.8)$ & 2.9 \\
\hline & Seborrheic dermatitis & $12(16.2)$ & 0.8 \\
\hline & Hand dermatitis & $8(10.8)$ & 0.6 \\
\hline & Chronic nonspecific dermatitis & $4(5.4)$ & 0.3 \\
\hline & Atopic dermatitis & $3(4.1)$ & 0.2 \\
\hline & Lichen simplex chronicus & $3(4.1)$ & 0.2 \\
\hline & Pompholyx & $2(2.7)$ & 0.1 \\
\hline Hypertrophic/atrophic skin & Keloid/hypertrophic scars & $45(67.2)$ & 3.1 \\
\hline disorders $(67,4.6)$ & Striae & $22(32.8)$ & $\mathrm{I} .5$ \\
\hline \multirow[t]{3}{*}{ Disorders of keratinization $(16,1.1)$} & Keratosis pilaris & $9(56.3)$ & 0.6 \\
\hline & Ichthyosis & $5(3 \mid .3)$ & 0.4 \\
\hline & Palmar keratoderma & $2(12.5)$ & 0.1 \\
\hline \multirow[t]{8}{*}{ Miscellaneous disorders (2I, I.4) } & Pityriasis rosea & $6(28.60$ & 0.4 \\
\hline & Phrynoderma & $4(19.0)$ & 0.3 \\
\hline & Angular cheilitis & $3(14.3)$ & 0.2 \\
\hline & Aphthous ulcers & $2(9.5)$ & 0.1 \\
\hline & Chronic leg ulcers & $2(9.5)$ & 0.1 \\
\hline & Dermatosis papulosa nigra & $2(9.5)$ & 0.1 \\
\hline & Lipodystrophy & I (4.8) & 0.1 \\
\hline & Telangiectasia & I (4.8) & 0.1 \\
\hline
\end{tabular}

The point prevalence of skin diseases was higher in students in private (high income) schools $(70.7 \%)$ than in public (low income) schools (61.3\%). Comparison of infective skin diseases in these two groups of schools showed a significantly higher preponderance of dermatophytosis in public schools $(P<0.05)$, while students in private schools had more pityriasis versicolor $(P=0.001)$ and papular urticaria $(P<0.05)$. The relevant details are shown in Table 4.

\section{Discussion}

This study was conducted in November 2008. The average temperature for the month was $31.6^{\circ} \mathrm{C}\left(88.9^{\circ} \mathrm{F}\right)$ and the average relative humidity was $87 \% .{ }^{16}$ The heat index, which is a measure of the human-perceived equivalent temperature, was thus calculated to be $46^{\circ} \mathrm{C}\left(115^{\circ} \mathrm{F}\right)$.

The point prevalence of $64.1 \%$ is comparable with that obtained from similar studies in Nigeria, ${ }^{10}$ Egypt,${ }^{17}$ and Saudi Arabia, ${ }^{18}$ but higher than that reported by Fung and $\mathrm{Lo}^{19}$ and 
Table 3 Comparison by gender of six commonest dermatoses

\begin{tabular}{|c|c|c|c|c|}
\hline \multirow[t]{2}{*}{ Skin disease } & \multirow{2}{*}{$\begin{array}{l}\text { Male }(\%) \\
(n=6 \mid 9)\end{array}$} & \multirow{2}{*}{$\begin{array}{l}\text { Female }(\%) \\
(n=828)\end{array}$} & \multicolumn{2}{|c|}{ Statistics } \\
\hline & & & $\chi^{2}$ & $P$-value \\
\hline All skin conditions & $446(72.1)$ & $483(58.3)$ & 29.003 & 0.001 \\
\hline Dermatophytes & $46(7.4)$ & $16(1.9)$ & 28.672 & 0.001 \\
\hline Acne vulgaris & $230(37.2)$ & $279(33.7)$ & 1.861 & 0.173 \\
\hline Pityriasis versicolor & $223(36.0)$ & $207(25.0)$ & 20.617 & 0.001 \\
\hline Miliaria & $24(3.9)$ & $37(4.5)$ & 0.307 & 0.580 \\
\hline Nevoid conditions & $63(10.2)$ & $33(4.0)$ & 21.926 & 0.001 \\
\hline $\begin{array}{l}\text { Keloid/hypertrophic } \\
\text { scars }\end{array}$ & $25(4.0)$ & $20(2.4)$ & 3.098 & 0.078 \\
\hline
\end{tabular}

Dogra and Kumar ${ }^{13}$ in Hong Kong and India, respectively. Prevalence rates in studies with an admixture of children and adolescents vary between $22.8 \%$ and $80.4 \%$ in different geographic and demographic populations..$^{10,12,13,18-23}$ The data for adolescents could only be obtained from two of these studies. ${ }^{10,21}$ Ogunbiyi et al ${ }^{10}$ reported a point prevalence of $70.8 \%$ in adolescents in south-west Nigeria, which is within the range seen in our results. In the second study, data on adolescents were extracted from a national population survey of skin conditions in Washington, DC, USA, ${ }^{21}$ and only stated the prevalence of significant skin diseases (38.8\%), implying that not all observed skin disorders were considered. Two studies reported the prevalence of skin disorders in young people, young referring to persons aged 10-24 years, which is an overlap of adolescents (10-19 years) and youth (15-24 years). ${ }^{1}$ The first was gleaned from a large-scale survey of persons aged 15-74 years in the UK, in which a point prevalence of $61.2 \%$ was reported among youths ${ }^{24}$ while Toraub and Jeewon ${ }^{25}$ showed a prevalence of $23.8 \%$ among young people aged 11-23 years in a less developed tropical country. The wide-ranging variations underscore the fact that the prevalence of skin disorders is determined by several factors, including age, race, genetics, climate, socioeconomic characteristics, religion, occupation, availability of health care practitioners with knowledge of the diagnosis and

Table 4 Comparison of infective skin diseases between public and private schools

\begin{tabular}{|c|c|c|c|}
\hline \multirow[t]{2}{*}{ Skin disease } & \multicolumn{2}{|c|}{ School type n (\%) } & \multirow[t]{2}{*}{$P$-value } \\
\hline & $\begin{array}{l}\text { Public } \\
(n=996)\end{array}$ & $\begin{array}{l}\text { Private } \\
(n=45 I)\end{array}$ & \\
\hline Dermatophytes & $51(5.12)$ & II (2.4) & 0.044 \\
\hline Candidiasis & $12(1.2)$ & $2(0.4)$ & 0.171 \\
\hline Pityriasis versicolor & $270(27.1)$ & $160(35.5)$ & 0.001 \\
\hline Papular urticaria & $8(0.8)$ & $10(2.2)$ & 0.025 \\
\hline Viral infections & $7(0.7)$ & $3(0.7)$ & 0.736 \\
\hline Bacterial infections & II (I.I) & $\mathrm{I}(0.2)$ & 0.086 \\
\hline Scabies & $3(0.3)$ & $\mathrm{I}(0.2)$ & 0.790 \\
\hline
\end{tabular}

appropriate treatment of skin diseases, and the study design of a given survey. The more diverse these factors, the more varied the prevalence and the more difficult it is to compare such studies. The effects of factors such as age, gender, and social class cancel out when all forms of skin diseases are considered together. This is because several conditions have trends in opposite directions, so that their cumulative effects cancel out when they are pooled. ${ }^{24}$ An example of this was seen in a survey of children and adolescents aged 6-21 years, in which less than $10 \%$ of persons aged 6-12.4 years had acne compared with more than $90 \%$ of those aged $12.5-21$ years, while $82.4 \%$ of the former group had atopic dermatitis compared with $17.6 \%$ of the latter group. ${ }^{19}$ Therefore, when relatively diverse groups such as childhood and adolescence are merged, there is a tendency to record lower prevalence values due to the cancelling-out effect. This constitutes a major reason for the marked variability in the prevalence in most of the aforementioned studies above. Other important reasons may include the nonuniformity in study design, diagnostic criteria, and disease definition.

A total of 42 specific skin conditions were diagnosed in our study, and were divided into seven categories, of which disorders of skin appendage formed the largest category. This was on account of acne vulgaris, which was the most common skin disease in the study at $35.1 \%$. It was also the commonest dermatosis in similar studies that strictly surveyed adolescents ${ }^{10}$ or included considerable numbers of young people. ${ }^{19,24,25}$ However, this was not the case in surveys including nonhomogeneous (children and adolescents) groups. ${ }^{12,20,22}$ Acne vulgaris is considered a disease of adolescence due to its high prevalence in certain adolescent age groups. In some studies, the prevalence of acne approaches $80 \%-100 \%{ }^{26,27}$

Miliaria was another condition that contributed to the bulk of disorders of skin appendage. It was among the six most common conditions in our study. Miliaria is a heatrelated dermatosis, and is often found in persons not used to hot and humid environments. It has been reported to be more common in Europeans living in a tropical zone than in native residents; ${ }^{28}$ and was also one of the most common diseases affecting US military personnel situated in the tropics during World War II. ${ }^{29}$ That such a condition should now be seen commonly among adolescent native residents of the tropics, may not be unconnected to the reality of the rising temperatures brought about by global warming. It is noteworthy that miliaria occurred more in females, many of whom were noticed to be wearing numerous layers of nylon vests/underwear underneath their school uniforms, which 
can generate a significant amount of heat in an already hot and humid region.

Pityriasis versicolor was the second most common condition. It was also the second commonest condition after acne vulgaris in a similar study in southwest Nigeria. ${ }^{10}$ It is a disease with an onset and/or peak in adolescence, and is a common tropical dermatosis caused by the yeast of the genus Malassezia, which is part of the normal skin flora but can be pathogenic, especially in a hot and humid climate. It has also been hypothesized to have a genetic basis for susceptibility. ${ }^{30,31}$

Dermatophytosis was found in $4.3 \%$ of our study population and was mostly due to tinea capitis, which occurred more often in younger adolescents. A few cases of tinea corporis were seen, mainly in females who used steroid creams routinely on a daily basis to "maintain their complexion". Regular use of steroid-containing creams has been associated with an increased susceptibility to skin infections such as tinea corporis..$^{32}$ Papular urticaria was also relatively common at $1.2 \%$, which is less than the prevalence of $8.5 \%$ reported by Ogunbiyi et al. ${ }^{10}$ Papular urticaria is a hypersensitivity reaction to insect bites, such as those from mosquitoes and sandflies, which thrive in areas of high temperature and humidity. The probable reason for the relatively lower prevalence of papular urticaria in our study may relate to the great emphasis attached to environmental sanitation by the government of Cross River State. This state is arguably the cleanest in Nigeria, and being a tourist destination, it strives to maintain a clean and green environment. This contributes to the well-kept environment around many of the schools that are devoid of dirty drains and untended shrubbery which are breeding sites for many insects.

Viral warts were not seen as often as in studies in Caucasian adolescents, ${ }^{12,33,34}$ but similar low prevalence rates are reported for other tropical zones like India ${ }^{13}$ and Hong Kong. ${ }^{19}$ The only other study on the pattern of skin diseases in adolescents in Nigeria ${ }^{10}$ did not find a single case of viral warts. The point prevalence of scabies $(0.2 \%)$ was similar to that obtained both in developed and urban areas of developing countries. ${ }^{10,19,35}$ Contrary to the widely held view that scabies is a disease of developing societies, it is a highly contagious ubiquitous disease with a worldwide distribution of 300 million persons annually. ${ }^{36,37}$ However, it is a disease associated with poverty, poor hygiene, malnutrition, overcrowding, and institutionalization, ${ }^{38,39}$ which are factors seen more in developing rural communities and urban slums, thus predisposing to parasitic infestation. ${ }^{36,40}$
Various forms of nevi, including melanocytic, congenital and acquired achromic, and epidermal nevi formed the bulk of skin pigment disorders, accounting for $73 \%$ of this category and $6.6 \%$ of all skin disorders. Melanocytic nevi were the most prevalent. These are better known as "birthmarks" by the public and are widely regarded as normal, due to their presence in a large number of persons and their asymptomatic nature. The high prevalence of melanocytic nevi in our study may not be unconnected to the high degree of sun exposure in the study population. This has been found to be directly proportional to the development of nevi. ${ }^{41}$

The high prevalence of keloid/hypertrophic scarring was not surprising, given that that is a common condition in dark-skinned individuals. It was one of the six most common conditions in our study.

Contact dermatitis was the predominant form of dermatitis seen. It was mainly due to a type of irritant contact dermatitis called paederus dermatitis from cantharidin, the chemical compound secreted by the blister beetle. Outbreaks of this type of dermatitis are common in Nigeria. ${ }^{42}$

There was a low point prevalence of atopic dermatitis $(0.2 \%)$, although a number of hospital-based surveys have shown a rising trend in Nigeria. ${ }^{8,43}$ The relatively older age of the study population may explain the low prevalence, and this hypothesis was borne out by Fung and $\mathrm{Lo}^{19}$ who found a prevalence of $2.8 \%$ in primary school students aged 6-12.4 years and $0.6 \%$ in their secondary school counterparts aged $12.5-21$ years.

In our study, there were gender variations in general and in some specific skin disorders. Skin diseases were significantly more common in males than females. A similar trend was reported in the USA, but unlike in our study, the finding was not statistically significant. ${ }^{21}$ El-Badawy et al ${ }^{17}$ reported a female predominance, while others found no gender difference in the sum of all dermatoses. ${ }^{12,13}$ This supports our finding that the effect of gender, just like age and social factors, cancels out when all skin diseases are considered. Thus, generalizations about the determinants of the entire range of skin diseases are limited because subgroups may exhibit trends in opposite directions. Males had more dermatophytosis, pityriasis versicolor, nevi, acne vulgaris, and keloids, although the predominance of the latter two conditions was not statistically significant. There was a female predominance for miliaria, but this was not statistically significant either. A number of other studies have confirmed a higher male prevalence for acne vulgaris. ${ }^{26,44,45}$ Mbuagbaw et $\mathrm{al}^{46}$ found a female predominance, while no differences were found in other studies. ${ }^{19,27}$ A male preponderance was also reported 
for dermatophytosis, ${ }^{19,47,48}$ pityriasis versicolor, ${ }^{31,49,50}$ and nevi. ${ }^{33,41,51,52}$ However, two studies were found that reported a higher frequency of pityriasis versicolor in females. ${ }^{10,53}$

Curiously, we found that students from private schools, which are high income schools with presumably more students in the higher socioeconomic class, had more skin diseases than their public (low income) school counterparts. The reason for this may be the younger age of private school students. As shown in Table 1, over $90 \%$ of students in private schools were young adolescents, and this group had more pityriasis versicolor and acne vulgaris than older adolescents, although the increased prevalence of the latter was not statistically significant. These two conditions were the most common in the study. Further, there is little regulation of drugs in the country, so older adolescents are more likely to have the resources and predisposition to buy over-the-counter medications. Our data for infective dermatoses showed public schools predominating in all but pityriasis versicolor and papular urticaria, which were more common in high income schools. The prevalence of viral warts was similar in both school types. Inanir et $\mathrm{al}^{22}$ reported similar findings of more infective dermatoses in a low income school and more acne vulgaris in a high income school.

Dermatology is a prototypical medical specialty in which the management principle of "vital few and trivial many" is evident. There are over 2,000 skin diseases that may present to a physician, ${ }^{54}$ yet surveys suggest that the bulk of skin diseases are made up of fewer than ten disorders. ${ }^{11}$ Six conditions, including acne vulgaris, pityriasis versicolor, dermatophytosis, nevi, miliaria, and keloid/hypertrophic scars, accounted for $83 \%$ of the total number of dermatoses seen in this study. This pattern of fewer than ten skin diseases comprising $\geq 80 \%$ of observed dermatoses has been documented by a number of other researchers. ${ }^{12,13,19}$ This makes it feasible to recruit and train a sizeable number of health care workers to recognize and treat common skin diseases; they will in turn be engaged in the care and dissemination of this knowledge in schools, thus reducing the magnitude of the skin health challenges in adolescents. In addition, there will be greater ease in the creation and implementation of policies by the relevant school health authorities regarding the skin health needs of adolescents.

In conclusion, this study suggests that skin diseases are common in adolescents in Calabar. There are marked similarities in the prevalence and pattern of skin diseases among adolescents in the southern part of Nigeria. Pityriasis versicolor, dermatophytosis, and miliaria are common conditions in the hot and humid climate of Calabar. Acne vulgaris and pityriasis versicolor are diseases of adolescence, keloid/hypertrophic scars are common in the negroid race, and nevi have a worldwide distribution, but more so in areas of increased sunshine. Thus, climate, age, and race are key factors determining the development of skin diseases in adolescents in Nigeria. Only a handful of treatable skin conditions account for the vast majority of skin diseases in the country. Thus, school health policies can be easily formulated to cater for the skin health needs of adolescents in Nigeria.

\section{Disclosure}

The authors report no conflicts of interest in this work.

\section{References}

1. Goodburn EA, Ross DA. A picture of health? A review and annotated bibliography of the health of young people in developing countries. Geneva, Switzerland: World Health Organization, World Health Organization, Adolescent Health Programme; 1995. Available from: https://extranet.who.int/iris/restricted/handle/10665/62500. Accessed March 22, 2014.

2. Central Intelligence Agency. The World Fact Book. Country Comparison to the World. Population; 2014. Available from: https://www.cia.gov/ library/publications/the-world-factbook/fields/2119.html. Accessed March 22, 2014.

3. United Nations Children's Fund. Statistics, 2011. At a glance: Nigeria Available from: http://www.unicef.org/infobycountry/nigeria_statistics. html. Accessed March 22, 2014.

4. Halvorsen JA, Stern RS, Dalgard F, Thoresen M, Bjertness E, Lien L. Suicidal ideation, mental health problems, and social impairment are increased in adolescents with acne: a population-based study. J Invest Dermatol. 2011;131:363-370.

5. Golics CJ, Basra MK, Finlay AY, Salek MS. Adolescents with skin diseases have specific quality of life issues. Dermatology. 2009;218: 357-366.

6. Khatami A, San Sebastian ML. Skin disease: a neglected public health problem. Dermatol Clin. 2009;27:99-101.

7. Akello G, Reis R, Ovuga E, Rwabukwali CB, Kabonesa C, Richters A. Primary school children's perspectives on common diseases and medicines used: implications for school healthcare programmes and priority setting in Uganda. Afr Health Sci. 2007;7:73-79.

8. Ogunbiyi AO, Daramola OO, Alese OO. Prevalence of skin diseases in Ibadan, Nigeria. Int J Dermatol. 2004;43:31-36.

9. Shakkoury WA, Abu-Wandy E. Prevalence of skin disorders among male school children in Amman, Jordan. ISME J. 1999;5:955-959.

10. Ogunbiyi AO, Omigbodun Y, Owoaje E. Prevalence of skin disorders in school children in southwest Nigeria. Int J Adolesc Med Health. 2009;21:235-241.

11. Williams HC. Dermatology. In: Stevens A, Raftery J, editors. Health Care Needs Assessment, Series II. Oxford, UK: Radcliffe Medical Press; 1997.

12. Popescu R, Popescu CM, Williams HC, Forsea D. The prevalence of skin conditions in Romanian school children. $\mathrm{Br} J$ Dermatol. 1999;140:891-896.

13. Dogra S, Kumar B. Epidemiology of skin diseases in school children: a study from Northern India. Pediatr Dermatol. 2003;20:470-473.

14. International Statistical Classification of Diseases and Related Health Problems 10th Revision. ICD-10 Version: 2008. Available from: http://apps who.int/classifications/icd10/browse/2008/en. Accessed May 6, 2014.

15. Burns DA, Breathnach S, Cox N, Griffiths C. Rook's Textbook of Dermatology. 7th ed. Oxford, UK: Blackwell Publishing Inc.; 2004.

16. Nigerian Meteorological Agency. Weather statistics: Calabar. Nigerian Meteorological Agency: Abuja, Nigeria; 2008. 
17. El Badawy AA, Selim AG, Abdelghaffar A, et al. Epidemiological study of the common dermatoses among school students in the Zagazig district of Egypt. Abstract 4205 presented at the 128th Annual Meeting of the American Public Health Association, November 12-16, 2000, Boston, MA, USA. Available from: https://apha.confex.com/apha/128am/ techprogram/paper_4205.htm. Accessed March 22, 2014.

18. Al-Khawajah MM, Al-Shammari S, Al-Mofadhi A, et al. Spectrum of dermatological disorders in school children in Saudi Arabia. Part 1. National guard school in Riyadh. J Saudi Soc Dermatol Venereol. 1997;5:214-221.

19. Fung WK, Lo KK. Prevalence of skin disease among school children and adolescents in a student health service center in Hong Kong. Pediatr Dermatol. 2000;17:440-446.

20. Bechelli LM, Haddad N, Pimenta WP, et al. Epidemiological survey of skin diseases in school children living in Porus Valley (Acre state, Amazonia, Brazil). Dermatologica. 1981;163:78-93.

21. Johnson M-LT, Roberts J. Prevalence of dermatological disease among persons 1-74 years of age: United States. Washington, DC, USA: United States Department of Health, Education and Welfare; 1977. Available from: http://www.cdc.gov/nchs/data/ad/ad004acc.pdf. Accessed March 22, 2014.

22. Inanir I, Sahin TM, Gunduz K, Dinc G, Turel A, Ozturkean S. Prevalence of skin conditions in Primary school children in Turkey: differences based on socioeconomic factors. Pediatr Dermatol. 2002;19(4): 307-311.

23. Figueroa JI, Hawranek T, Abraha A, Hay RJ. Prevalence of skin diseases in school children in rural and urban communities in the Illubabor province, south-western Ethiopia: a preliminary survey. $J$ Eur Acad Dermatol Venereol. 1997;9:142-148.

24. Rea JN, Newhouse ML, Halil T. Skin diseases in Lambeth: a community study of prevalence and use of medical care. Br J Prev Soc Med. 1976;30:107-114.

25. Toraub K, Jeewon R. Sociodemographic factors and their association to prevalence of skin diseases among adolescents. Our Dermatology Online. 2013;4:281-286.

26. Burton JL, Cunliffe WJ, Stafford I, Shuster S. The prevalence of acne vulgaris in adolescence. Br J Dermatol. 1971;85:119-126.

27. Yahya $H$. Acne vulgaris in Nigerian adolescents - prevalence, severity, beliefs, perceptions, and practices. Int J Dermatol. 2009;48:498-505.

28. Shrank AB, Harman RRM. The incidence of skin diseases in a Nigerian teaching hospital dermatology clinic. $\mathrm{Br} J$ Dermatol. 1966;78:235-241.

29. Pillsbury DM, Livingood CS. Dermatology. In: Havens WP, Anderson RS, editors. Infectious Diseases and General Medicine. Internal Medicine in World War II. Washington, DC, USA: Medical Department, US Army, Office of The Surgeon General; 1968;3.

30. Hafez M, El-Shamy S. Genetic susceptibility in pityriasis versicolor. Dermatologica. 1985; 17:86-88.

31. He SM, Du WD, Yang S, et al. The genetic epidemiology of pityriasis versicolor in China. Mycoses. 2008;51:55-62.

32. Olasode OA, Akpan NA, Bisong EB. Severe tinea corporis resulting from the use of topical steroids as skin lightening cream - report of three cases. Sudanese Journal of Dermatology. 2008;5:67-71.

33. Larsson PA, Liden S. Prevalence of skin diseases among adolescents 12-16 years of age. Acta Derm Venereol. 1980;60:415-423.

34. Kilkenny M, Merlin K, Young R, Marks R. The prevalence of common skin conditions in Australian school students. 1. Common, plane and plantar viral warts. Br J Dermatol. 1998;138:840-845.
35. Lassa S, Campbell MJ, Bennett CE. Epidemiology of scabies prevalence in the UK from general practice records. Br J Dermatol. 2011;164: 1329-1334.

36. Heukelbach J, Wilcke T, Winter B, Feldmeier H. Epidemiology and morbidity of scabies and pediculosis capitis in resource-poor communities in Brazil. Br J Dermatol. 2005;153:150-156.

37. Hengge UR, Currie BJ, Jager G, et al. Scabies: a ubiquitous neglected skin disease. Lancet Infect Dis. 2006;6:769-779.

38. Green MS. Epidemiology of scabies. Epidemiol Rev. 1989;11: 126-150.

39. Cox NH, Paterson WD. Epidemiology of scabies: the new epidemic. Lancet. 1991;22:1547-1548.

40. Figueroa JI, Fuller CL, Abraha A, Hay RJ. The prevalence of skin disease among school children in rural Ethiopia - a preliminary assessment of dermatologic needs. Pediatr Dermatol. 1996;13:378-381.

41. Fritschi L, McHenry P, Green A, et al. Naevi in school children in Scotland and Australia. Br J Dermatol. 1994;130:599-603.

42. George AO, Hart PD. Outbreak of paederus dermatitis in southern Nigeria: epidemiology and dermatology. Int J Dermatol. 1990;29: $500-501$.

43. Nnoruka EN. Skin diseases in south-east Nigeria. A current perspective. Int J Dermatol. 2005;44:29-33.

44. Shen Y, Wang T, Zhou C, et al. Prevalence of acne vulgaris in Chinese adolescents and adults: a community-based study of 17,345 subjects in six cities. Acta Derm Venereol. 2012;92:40-44.

45. Lello J, Pearl A, Arroll B, Yallop J, Birchall NM. Prevalence of acne vulgaris in Auckland senior high school students. $N Z$ Med J. 1995; 108:287-289.

46. Mbuagbaw J, Abongwa C, Ozoh G, Blackett K. The prevalence of acne vulgaris in secondary school students in Yaoundé, Cameroon. The Internet Journal of Dermatology. 2006;5(2).

47. Pau M, Atzori L, Aste N, Tamponi R, Aste N. Epidemiology of tinea pedis in Cagliari, Italy. G Ital Dermatol Venereol. 2010;145:1-5.

48. Ndako JA, Osemwegie OO, Spencer THI, Olopade BK, Yunusa GA, Banda J. Prevalence of dermatophytes and other associated fungi among school children. Global Advanced Research Journal of Medicine and Medical Sciences. 2012;1:49-56.

49. Ghosh SK, Dey SK, Saha I, Barbhuiya JN, Ghosh A, Roy AK. Pityriasis versicolor: a clinicomycological and epidemiological study from a tertiary care hospital. Indian J Dermatol. 2008;53: $182-185$.

50. El-Hefnawi H, El-Gothany Z, Refai M. Studies on pityriasis versicolor in Egypt: I. Incidence. Mykosen. 1971;14:225-231.

51. Csoma Z, Erdei Z, Bartusek D, et al. The prevalence of melanocytic naevi among school children in South Hungary. $J$ Eur Acad Dermatol Venereol. 2008;22(12):1412-1422.

52. Darlington S, Siskind V, Green L, Green A. Longitudinal study of melanocytic nevi in adolescents. J Am Acad Dermatol. 2002;46: 715-722.

53. Ebrahimzadeh A. A survey of pityriasis versicolor in the university students in Southeast of Iran. Asian J Dermatol. 2009;1:1-5.

54. Burns DA, Cox NH. Introduction and historical bibliography. In: Burns T, Breathnach S, Cox N, Griffiths C, editors. Rook's Textbook of Dermatology. Turin, Italy: Blackwell Publishing; 2004. 
Adolescent Health, Medicine and Therapeutics

Dovepress

\section{Publish your work in this journal}

Adolescent Health, Medicine and Therapeutics is an international, peer-reviewed, open access journal focusing on health, pathology, and treatment issues specific to the adolescent age group. All aspects of health maintenance, preventative measures and disease treatment interventions are addressed within the journal and practitioners from all disciplines are invited to submit their work as well as healthcare researchers and patient support groups.. The manuscript management system is completely online and includes a very quick and fair peerreview system. Visit http://www.dovepress.com/testimonials.php to read real quotes from published authors.

Submit your manuscript here: http://www.dovepress.com/adolescent-health-medicine-and-therapeutics-journal 